\title{
Comprehensive analysis of hepatic gene and protein expression profiles on phenobarbital- or clofibrate-induced hepatic hypertrophy in dogs
}

\author{
Toshihiko Makino1,2, Junzo Kinoshita1, Shingo Arakawa', Kazumi Ito', Yosuke Ando', \\ Takashi Yamoto', Munehiro Teranishi'1, Atsushi Sanbuissho' ${ }^{1}$ and Hiroyuki Nakayama ${ }^{2}$ \\ ${ }^{1}$ Medicinal Safety Research Laboratories, Daiichi Sankyo Co., Ltd., 717 Horikoshi, Fukuroi, Shizuoka 437-0065, \\ Japan \\ ${ }^{2}$ Department of Veterinary Pathology, Graduate School of Agricultural and Life Sciences, University of Tokyo, 1-1-1 \\ Yayoi, Bunkyo-ku, Tokyo 113-8657, Japan
}

(Received August 18, 2009; Accepted September 14, 2009)

\begin{abstract}
In order to characterize the hepatic effects of phenobarbital (PB) and clofibrate (CPIB) in dogs, PB and CPIB were administered to male beagle dogs for 14 days, and biochemical and histopathological examinations and comprehensive genomic and proteomic analyses, including GeneChip ${ }^{\circledR}$ analysis and proteomics analysis using the 2-dimension difference gel electrophoresis (2D-DIGE) technique, were performed. Both compounds caused centrilobular hepatocellular hypertrophy, which were related to smooth endoplasmic reticulum (SER) proliferation in PB-treated dogs and to mitochondrial proliferation in CPIB-treated dogs. In the PB-treated dogs, drug-metabolizing enzyme induction was observed by Western blot and genomic analyses. CYP proteins could not be detected by the 2D-DIGE analysis, but increases in several endoplasmic reticulum (ER)-related proteins were observed. In the CPIB-treated dogs, drug-metabolizing enzyme induction was not clearly observed by any of Western blot, genomic and proteomic analyses. Genomic and proteomic analyses revealed that mitochondrial genes and proteins, including carnitine palmytoiltransferase II, acyl-CoA deheydrogenase and hydroxyacyl-CoA dehydrogenase, pyruvate carboxylase and ATP synthase beta chain were induced. There is a relatively good correlation among the morphology and the genomic and proteomic data, but some differences exist between the genomic and proteomic data. Comprehensive evaluation using these techniques in addition to morphological evaluation may provide a useful tool for safety assessment of the liver.
\end{abstract}

Key words: Phenobarbital, Clofibrate, Liver, Microarray, 2-dimension difference gel electrophoresis, Dog

\section{INTRODUCTION}

Drug metabolizing enzymes have an important role in the biotransformation and elimination of xenobiotics. During the development of new drugs, their ability to induce drug metabolizing enzymes and the prediction or explanation of the drug-drug interactions in humans are determined. The induction of hepatic drug-metabolizing enzymes in human and rodent livers has been fully investigated and a considerable amount of information has been accumulated (Amacher, 2006; Graham and Lake, 2008). Beagle dogs are widely used in the pharmaceutical industry during drug development and are an important animal model in the safety assessment of drugs. However, relatively little information is available in the literature on the inducibility of hepatic drug-metabolizing enzymes in dogs.

It has been reported that species differences in response to the administration of some compounds exist and that these species differences may complicate the extrapolation of the drug effects observed in rodents and non-rodents during non-clinical studies to humans. Peroxisome proliferators are well-known to have such species differences and to cause hepatocellular carcinoma in rodents (Morimura et al., 2006). They are non-genotoxic carcinogens that do not require metabolic activation in

Correspondence: Toshihiko Makino (E-mail: makino.toshihiko.f7@daiichisankyo.co.jp) 
order to exert their harmful effects. While a direct relationship between peroxisome proliferation and hepatocellular carcinoma observed in rodents has not yet been clearly elucidated, it is considered that an increase in the number and activity of peroxisomes leads to increased production of the reactive oxygen species generated by peroxisomal enzymes, which contribute to the carcinogenicity of peroxisome proliferators (Lai, 2004; Gonzalez, 2002). PPAR $\alpha$-deficient mice are resistant to peroxisome proliferators and hepatocarcinogenesis, which suggests that peroxisome proliferation and carcinoma are closely dependent on the presence of PPAR $\alpha$ (Gonzalez, 2002). Humans and monkeys are less sensitive to peroxisome proliferators in comparison to rats and mice (Youssef and Badr, 1998). Many reports (Kane et al., 2006) have suggested that chronic administration of fibrate to patients in clinical studies neither induces peroxisome proliferation nor elevates the risk of tumors in the liver. The peroxisome proliferation observed in livers treated with peroxisome proliferators has been considered to be a rodentspecific response and human hepatocytes exhibit neither such peroxisome proliferation nor hepatocarcinogenesis. It is important for the risk assessment of peroxisome proliferators in humans to investigate the mechanism of the species differences. However, few in vivo reports describing the effects of the peroxisome proliferators in dog liver are available (Kelley et al., 1994).

Clofibrate (CPIB) is one of the fibrate drugs and has the effect of lowering the levels of blood triglyceride and low-density lipoprotein cholesterol through PPAR $\alpha$ activation (Léonard et al., 2006; Fruchart et al., 1998). PPAR $\alpha$ is a member of the nuclear receptor superfamily and is recognized as a molecular target of hypolipidemic fibrate drugs. CPIB induces several drug-metabolizing enzymes and causes consequent hepatomegaly that is characterized by centrilobular hypertrophy of hepatocytes, hepatocyte proliferation and peroxisome proliferation in rodents (Léonard et al., 2006; David et al., 1999) and therefore this drug has been categorized as a peroxisome proliferator. It is well documented that peroxisome proliferators induce peroxisomal fatty acid $\beta$-oxidation, such as acyl-CoA oxidase (AOX) and microsomal $\omega$ oxidation by CYP4A enzymes and elevated metabolism and transport of fatty acids (Desvergne and Wahli, 1999; Graham et al., 2006). Peroxisomes are one of the subcellular organelles that perform a number of functions, including metabolizing the $\beta$-oxidation of fatty acids and cholesterol.

Phenobarbital (PB), a classical antiseizure medication for human epileptics, induces several drug-metabolizing enzymes such as CYP2B through constitutive andros- tane receptors, and also induces hepatomegaly related to centrilobular hypertrophy of hepatocytes and hepatocyte proliferation in various species. Ultrastructurally, smooth endoplasmic reticulum (SER) is increased in PBtreated hepatocytes. PB has a hepatopromotional effect in rodents, but it is known to be non-genotoxic (Sanders and Thorgeirsson, 1999).

In the present study, beagle dogs were treated with the typical drug-metabolizing enzyme inducers CPIB and PB for 14 days and comprehensive genomic and proteomic analyses were conducted on the livers using GeneChip ${ }^{\circledR}$ and a 2-dimension difference gel electrophoresis (2DDIGE) system. We then discuss the species differences between rats and dogs in terms of the hepatic responses caused by these drug-metabolizing enzyme inducers.

\section{MATERIALS AND METHODS}

\section{Animal treatment}

PB and CPIB were purchased from Sigma-Aldrich (St. Louis, MO, USA). Male beagle dogs were obtained from NARC CORPORATION (Chiba, Japan). The dogs were individually housed in stainless steel cages. The animal rooms for the dogs were controlled at a room temperature of 18 to $28^{\circ} \mathrm{C}$, and a relative humidity of 30 to $70 \%$, and were ventilated about 10 times/hr with lighting for 12 hr/day. The dogs were administered PB or CPIB by gavage at increasing dose levels for 14 days (PB: $20 \rightarrow 40 \rightarrow$ $60 \mathrm{mg} / \mathrm{kg}$, CPIB: $50 \rightarrow 100 \rightarrow 150 \mathrm{mg} / \mathrm{kg}$ ). Each group consisted of 3 dogs. The dose levels and duration were set according to the preliminary study results. Twentyfour hr after the last treatment, the dogs were anesthetized intravenously with pentobarbital sodium (Somnopentyl Injection: Kyoritsu Seiyaku Corporation, Tokyo, Japan), euthanized by exsanguination from the carotid arteries, autopsied, and examined macroscopically. The experimental protocol was approved by the Ethics Review Committee for Animal Experimentation of Daiichi Sankyo Co., Ltd..

\section{Histopathology and transmission electron microscopy}

The livers were weighed, fixed in $10 \%$ neutral buffered formalin and embedded in paraffin. Histopathological sections $(4 \mu \mathrm{m})$ were stained with hematoxylin and eosin (HE), and examined by light microscopy. The liver tissue samples for electron microscopy were cut into small pieces immediately after collection and pre-fixed in a mixture of $2 \%$ glutaraldehyde and $2 \%$ paraformaldehyde $(0.1 \mathrm{M}$ phosphate buffer solution, $\mathrm{pH} 7.4)$ at $4{ }^{\circ} \mathrm{C}$ for $2 \mathrm{hr}$ or more. The fixed tissues were post-fixed in 
Hepatic gene and protein expression profiles in dogs

$2 \%$ osmium tetraoxide solution $(0.1 \mathrm{M}$ phosphate buffer solution, $\mathrm{pH} \mathrm{7.4)}$ at $4{ }^{\circ} \mathrm{C}$ for $2 \mathrm{hr}$. Thereafter, the tissues were embedded in a resin (poly/Bed 812: Polysciences Inc. Warrington, PA, USA), ultrathin-sectioned and double stained with uranium and lead. The prepared sections were examined under a transmission electron microscope (JEM-2010: JEOL Ltd., Tokyo, Japan).

\section{Measurement of drug-metabolizing enzymes}

The liver samples were homogenized in $1.15 \% \mathrm{KCl}$. The homogenate was then centrifuged at $9,000 \times \mathrm{g}$ at $4^{\circ} \mathrm{C}$ for $20 \mathrm{~min}$, and the supernatant was centrifuged again at $105,000 \times \mathrm{g}$ at $4^{\circ} \mathrm{C}$ for $60 \mathrm{~min}$. The resultant supernatant was used as a cytosolic fraction. The pellet was resuspended in $1.15 \% \mathrm{KCl}$ containing $20 \%$ glycerol and then used as a microsomal fraction. Cytochrome P450 contents and 7-alkoxycoumarin O-dealkylase (ACD) activities, including 7-methoxycoumarin O-demethylase (MCD), 7-ethoxycoumarin O-deethylase (ECD), and 7-propoxycoumarin O-depropylase (PCD) activities, were measured according to the methods of Omura and Sato (1964), and Matsubara et al. (1983), respectively. Glutathione $S$-transferase activity was measured using DCNB or CDNB as a substrate (GST-D and GST-C activities, respectively) by the method of Habig et al. (1974). The UDP-glucuronosyltransferase activity (UDP-GT) was measured using $p$ nitrophenol as a substrate by the method of Bock et al. (1973). The protein concentrations of the microsome and cytosol were determined according to the method of Lowry et al. (1951) using bovine serum albumin as a standard.

\section{Western blot analysis}

The microsomal fraction was diluted to $2 \mathrm{mg} / \mathrm{ml}$ with $1.15 \% \mathrm{KCl}$ containing $20 \%$ glycerol and then diluted to $1 \mathrm{mg} / \mathrm{ml}$ with Tris-SDS BME Sample Loading Buffer. The samples were heated at $95^{\circ} \mathrm{C}$ for $5 \mathrm{~min}$ and electrophoresed on $7.5 \%$ SDS-polyacrylamide gel (EASYGELL, Funakoshi Co., Ltd., Tokyo, Japan) and then transferred electrophoretically onto Immobilon PVDF Transfer Membranes (Daiichi Pure Chemicals Co., Ltd., Tokyo, Japan) (Burnette, 1981). The membranes were incubated with primary antibodies and streptavidin-horseradish peroxidase conjugate and then ECD Western blotting detection reagent (GE Healthcare Bio-Sciences KK, Tokyo, Japan).

\section{Microarray analysis}

The liver samples were homogenized and the total RNA was isolated using an RNeasy Mini Kit (QIAGEN, Valencia, CA, USA), according to the manufacturer's instructions. Microarray analysis using the GeneChip ${ }^{\circledR}$ Canine Genome 2.0 array was performed individually according to the Affymetrix standard protocol. GeneChip ${ }^{\circledR}$ array was washed and stained using Fluidics Station 450 (Affymetrix Inc., Santa Clara, CA, USA) and scanned with a GeneChip ${ }^{\circledR}$ Scanner 3000 (Affymetrix Inc.). The microarray image data obtained from the dog livers were analyzed with GCOS ver. 1.0 (Affymetrix Inc.) and Spotfire 7.0 (Spotfire Inc., Somerville, MA, USA) software. The data were then normalized by the trimmed-mean normalization method, where the global mean was normalized after trimming the top $2 \%$ and bottom $2 \%$ of the GeneChip data (Yang et al., 2001). The fold change of the mRNA level was calculated by dividing the mean signal value of the PB- or CPIB-treated dogs by that of the control dogs. Gene probes which satisfied the following two conditions were selected as affected gene probes: 1 ) probes whose signal values were statistically different from those of corresponding controls: 2) probes whose mean fold-change between the treated and corresponding control groups were determined to be above 1.5 (up-regulated) and below 0.66 (down-regulated).

\section{D-DIGE and mass spectrometry}

\section{Sample preparation}

The liver samples were homogenized in a lysis buffer containing $30 \mathrm{mM}$ Tris- $\mathrm{HCl}, 7 \mathrm{M}$ urea, $2 \mathrm{M}$ thiourea, $5 \mathrm{mM}$ magnesium acetate, 4\% (w/v) CHAPS, and $0.5 \mathrm{mM}$ Pefabloc SC PLUS (Roche Diagnostics GmbH, Mannheim, Germany), and the homogenates were centrifuged at 850 $\times \mathrm{g}$ at $4^{\circ} \mathrm{C}$ for $20 \mathrm{~min}$. The supernatant was centrifuged again at $20,000 \times \mathrm{g}$ at $4^{\circ} \mathrm{C}$ for $10 \mathrm{~min}$. The protein concentration in the supernatants was measured by the method of Bradford (1976) using apo-transferrin as a control. The final supernatant was stored at $-80^{\circ} \mathrm{C}$ until use. The protein extracts of the individual animals were labeled with cyanine dyes (Cy2, Cy3 and $\mathrm{Cy} 5)$ according to the manufacturer's instructions (GE Healthcare Bio-Sciences Corp., Piscataway, NJ, USA). Briefly, $50 \mu \mathrm{g}$ of the protein extracts from the treated and control animals was labeled with 400 pmol of Cy3 or Cy5. A mixture of the protein extracts $(50 \mu \mathrm{g})$ from all the animals was labeled with 400 pmol of Cy2 to provide an internal standard.

\section{D-DIGE}

The labeled protein samples were mixed with an equal volume of $2 \mathrm{x}$ sample buffer containing $7 \mathrm{M}$ urea, $2 \mathrm{M}$ thiourea, 4\% (w/v) CHAPS, 2\% (v/v) Pharmalyte ( $\mathrm{pH}$ 3-10) and 2.4\% (v/v) DeStreak Reagent (GE Healthcare Bio-Sciences Corp.), and rehydration buffer containing 7 
M urea, 2 M thiourea, 4\% (w/v) CHAPS, 1\% (v/v) Pharmalyte (pH 3-10) and 1.2\% (v/v) DeStreak Reagent were added to make $450 \mu 1$ for the total sample volume. The final protein samples were applied to IPG strips (pH 3-10) (GE Healthcare Bio-Sciences Corp.) and subjected to isoelectric focusing (IEF) at $64,000 \mathrm{Vh}$ using the IPGphor IEF System (GE Healthcare Bio-Sciences Corp.) after rehydration of the IPG strip for $12 \mathrm{hr}$ under light-shaded conditions. After IEF, the IPG strips were equilibrated with $10 \mathrm{ml}$ buffer containing $6 \mathrm{M}$ urea, $50 \mathrm{mM}$ Tris- $\mathrm{HCl}(\mathrm{pH}$ $8.8), 30 \%(\mathrm{v} / \mathrm{v})$ glycerol, $2 \%(\mathrm{w} / \mathrm{v})$ SDS and $0.5 \%(\mathrm{w} / \mathrm{v})$ DTT for $10 \mathrm{~min}$, and then for a further $10 \mathrm{~min}$ with the same buffer without DTT and adding 4.5\% (w/v) iodoacetamide. The equilibrated strips were transferred onto $12.5 \%$ polyacrylamide gels $(25 \times 20 \times 0.1 \mathrm{~cm})$. The separation of the proteins according to their molecular weights was performed on the gels including $25 \mathrm{mM}$ Tris buffer containing $192 \mathrm{mM}$ glycine and $0.1 \%(\mathrm{w} / \mathrm{v}) \mathrm{SDS}$ at $10^{\circ} \mathrm{C}$ overnight under light-shaded conditions using an EttanDALT II System (GE Healthcare Bio-Sciences Corp.).

\section{Image analysis}

To acquire images of the developed proteins, the gels were scanned at the specific excitation wavelength of each cyanine fluorescence dye using a Typhoon 9400 (GE Healthcare Bio-Sciences Corp.) according to the manufacturer's instructions. Image analysis was performed using DeCyder software (version 5.02) (GE Healthcare Bio-Sciences Corp.). Protein spots from the gel images were detected by running the Batch Processor/Differential Image Analysis module of DeCyder. The Biological Variation Analysis module of the software was used to match protein spots between the gels and to perform a statistical analysis of the up- or down-regulated spots between the treated and control groups. The expression levels of each protein spot were evaluated by the spot volume ratio as compared to the internal standard. The protein spots showing significantly different $(P<0.05)$ of expresson levels by a Student's $t$-test and spots which had a fold change equal to or greater than 1.3 in absolute value between the treated and control groups were classified as up- or down-regulated spots.

\section{Spot picking}

Protein spots that were significantly up- or down-regulated between the control and treated animals in the 2DDIGE analysis were subjected to protein identification. Protein extracts $(400 \mu \mathrm{g})$ containing $50 \mu \mathrm{g}$ of Cy2-labeled proteins were separated by IEF and SDS-PAGE and the spots were scanned with the Typhoon 9400 in the abovementioned manner. The obtained images were matched to the spots that were significantly up- or down-regulated in the analytical gels and picking lists were created. The listed spots were automatically excised from the gels using an Ettan-spot picker (GE Healthcare Bio-Sciences Corp.) and stored at $-80^{\circ} \mathrm{C}$ until use.

\section{In-gel tryptic digestion}

The gel pieces were washed twice in $50 \%(\mathrm{v} / \mathrm{v})$ methanol containing $50 \mathrm{mM}$ ammonium bicarbonate for 20 min, dehydrated in $75 \%(\mathrm{v} / \mathrm{v})$ acetonitrile, and dried completely by vacuum centrifugation. The proteins were digested at $37^{\circ} \mathrm{C}$ overnight with a sequencing grade modified trypsin solution (Promega, Madison, WI, USA, 10 $\mathrm{ng} / \mathrm{l}$ in $20 \mathrm{mM}$ ammonium bicarbonate). After digestion, the peptides in each gel piece were eluted sequentially in $50 \%(\mathrm{v} / \mathrm{v})$ acetonitrile with $1 \%(\mathrm{v} / \mathrm{v})$ TFA, $50 \%(\mathrm{v} / \mathrm{v})$ acetonitrile with $0.2 \%(\mathrm{v} / \mathrm{v}) \mathrm{TFA}$, and $100 \%$ acetonitrile, by sonicating, and dried after concentration and desalination by vacuum centrifugation and a Zip Tip C18 pipette tip (Millipore Corp., Billerica, MA, USA).

\section{MALDI-TOF MS}

The peptides were re-suspended in $11 \mathrm{CHCA}$-saturated matrix solution containing $0.5 \%(\mathrm{v} / \mathrm{v})$ TFA and $50 \%$ $(\mathrm{v} / \mathrm{v})$ acetonitrile. The 0.51 peptide solution was transferred onto the MALDI target and dried. Mass spectrometry of the peptides was performed using an Ettan MALDIToF Pro (GE Healthcare Bio-Sciences Corp.) according to the manufacturer's instructions. For protein identification, the obtained mass information was searched against the NCBI nr database using Ettan MALDI-ToF software (version 1.11) (GE Healthcare Bio-Sciences Corp.).

\section{Statistical analyses}

The mean values and standard deviations were calculated for each group. For the body weight, organ weight and drug-metabolizing enzyme measurement, statistical analysis was performed by a Dunnett's test. For the microarray analysis, the data were analyzed by an $F$-test to evaluate the homogeneity of variance. If the variance was homogeneous, a Student's $t$-test was applied. If the variance was heterogeneous, an Aspin-Welch's $t$-test was performed. In every statistical analysis, a level of $P<0.01$ or $<0.05$ was considered significant.

\section{RESULTS}

\section{Liver weight and light microscopy}

PB treatment caused a statistically significant increase in the relative liver weight $(+85 \%)$. Similarly, CPIB treatment caused a $46 \%$ increase in the relative liver weight 
Hepatic gene and protein expression profiles in dogs

(Fig. 1). Histopathologically, both compounds caused centrilobular hypertrophy of the hepatocytes consistent with the increase in liver weight. The cytoplasm of the hepatocytes treated with PB showed a ground glass appearance and that treated with CPIB showed increased eosinophilic granules in the cytoplasm (Figs. 2A-C).

\section{Transmission electron microscopy}

SER proliferation was observed in the hepatocytes of PB-treated dogs by electron microscopy (Fig. 3B). On the other hand, proliferation of mitochondria without peroxisome proliferation was observed in the hepatocytes of the CPIB-treated dogs (Fig. 3C).

\section{Measurement of drug-metabolizing enzymes}

Dogs treated with PB showed significant increases in P450 contents (4.1-fold), and ECD (7.3-fold) and UDPGT activities (2.3-fold). MCD, PCD and GST-D activities were also significantly increased (Table 1). CPIB treatment, however, induced no significant changes in the P450 contents or drug-metabolizing enzyme activities.

\section{Western blot analysis}

In dogs treated with $\mathrm{PB}$, proteins cross-reacting with anti-dog CYP2B11 and CYP3A12 antibodies were markedly increased. Slight increases in proteins cross-reacting with anti-dog CYP2C21 and anti-human UGT2B4 antibodies and slight decreases in those cross-reacting with anti-rat CYP4A and anti-dog CYP1A antibodies were also

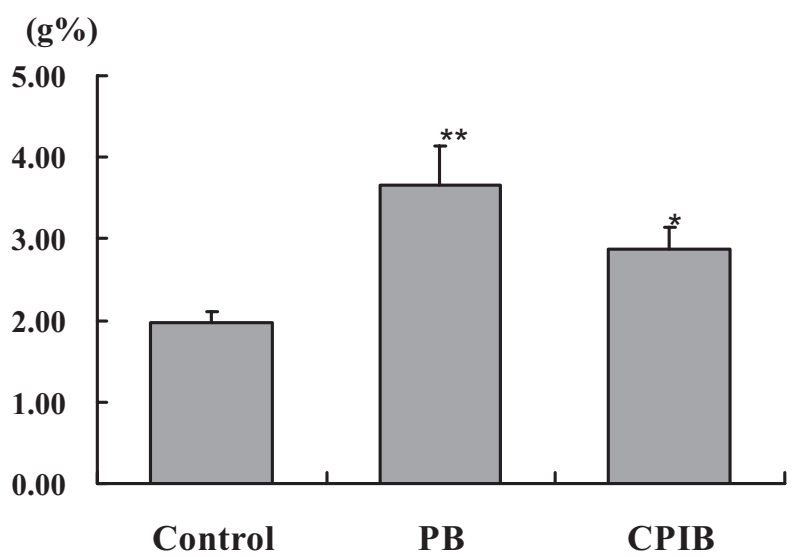

Fig. 1. Relative liver weight. Male beagle dogs were given PB $(20 \rightarrow 40 \rightarrow 60 \mathrm{mg} / \mathrm{kg} /$ day $)$ or CPIB $(50 \rightarrow 100$ $\rightarrow 150 \mathrm{mg} / \mathrm{kg} /$ day) by gavage. Animals were autopsied 14-days after the treatment and livers were collected and weighed. Data are expressed as mean relative liver weight $(\mathrm{g} \%) \pm$ S.D.. Significantly different from the control $\left({ }^{*} P<0.05,{ }^{* *} P<0.01\right)$. observed (Fig. 4). In dogs treated with CPIB, there was no change in proteins cross-reacting with anti-rat CYP4A antibody, while marked increases in proteins cross-reacting with anti-rat CYP2E1 antibody were observed (Fig. 4).

\section{Microarray analysis}

The GeneChip ${ }^{\circledR}$ data were expressed as heat maps for the Average Difference to control, Absolute Call and $p$ values (Figs. 5 and 6). The hepatic mRNA levels of several phase I and phase II drug-metabolizing enzymes genes were changed. In the PB-treated group, the gene expressions of CYP2B and CYP3A family enzymes were increased, while the expressions of the CYP1A, CYP2E and CYP4A genes were decreased. In the CPIB-treated group, the gene expressions of CYP2B and CYP3A family enzymes were decreased and there were no changes in that of CYP4A. The hepatic mRNA levels of other proteins than drug-metabolizing enzymes were also changed. In the CPIB-treated group, the mRNA levels of mitochondrial $\beta$-oxidation-related genes such as carnitine palmytoiltransferase, acyl-CoA deheydrogenase and hydroxyacyl-CoA dehydrogenase were increased, but the mRNA levels of peroxisomal $\beta$-oxidation-related genes were not changed (Fig. 7).

\section{D-DIGE}

To avoid false positives, only spots with a fold change above 1.3 or below 0.77 and a $p$ value $<0.05$ (Student's $t$-test) were taken into consideration. A total of 65 and 89 spots were significantly up-regulated in the PB- and CPIB-treated livers, respectively, and a total of 66 and 80 spots were significantly down-regulated in the PB- and CPIB-treated livers, respectively. A list of the proteins identified by MS is shown Tables 2 and 3. The proteins are grouped according to their respective roles. Among the proteins identified in the canine liver, those related to the mitochondria, peroxisome or endoplasmic reticulum (ER) are indicated in Fig. 8. In the PB-treated liver, 5 up-regulated spots corresponding to the ER proteins, 4 down-regulated spots corresponding to the peroxisomal proteins, and 1 down-regulated spot corresponding to the mitochondrial proteins were observed. In the CPIBtreated liver, 13 up-regulated spots corresponding to the mitochondrial proteins and 3 down-regulated spots corresponding to the peroxisomal proteins were observed. There were no spots which corresponded to the ER-related proteins in the CPIB-treated liver.

\section{DISCUSSION}

In the present study, biochemical, morphological, 


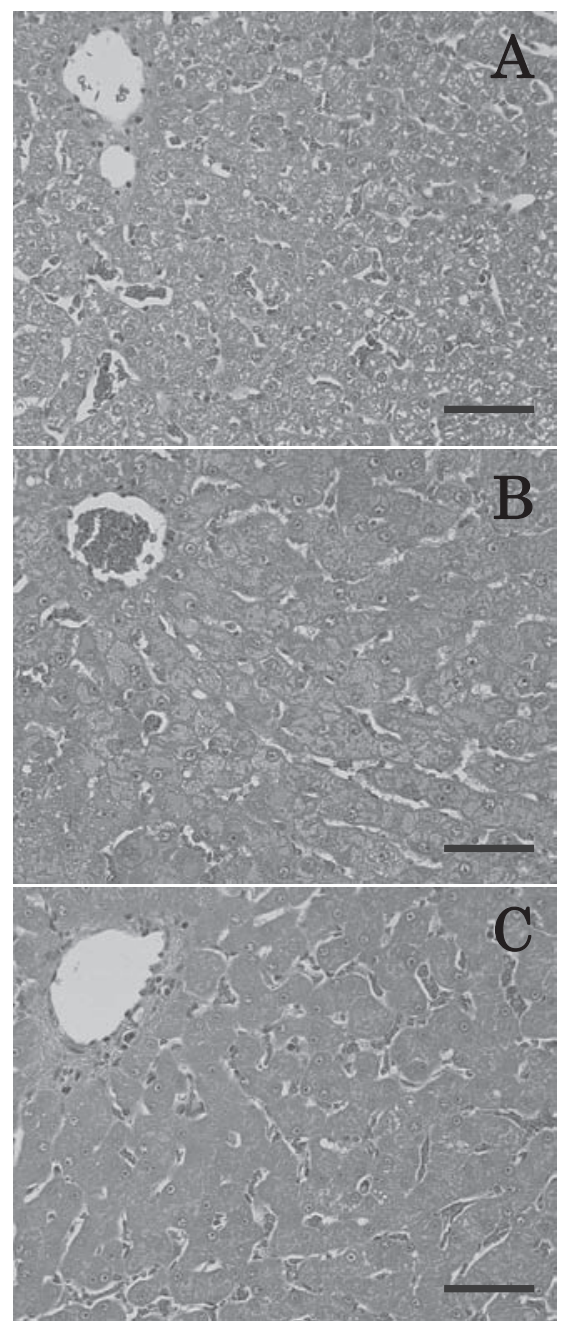

Fig. 2. Livers treated with chemicals for 14 days. Bar $=50$ $\mu \mathrm{m}$. A: Control, B: PB, C: CPIB. Hepatocytes treated with $\mathrm{PB}$ showed ground glass appearance and those treated with CPIB showed eosinophilic granular cytoplasm.

genomic and proteomic analyses were performed using dog livers treated with PB or CPIB, and the characteristics of the changes were compared.

PB treatment resulted in hepatomegaly, centrilobular hypertrophy of the hepatocytes related to SER proliferation and drug metabolizing enzyme induction, such as CYP2B, CYP3A and UDP-GT. These observations were similar to those previously reported in rats (Makino et al., 1998). In contrast to PB, the observations in CPIB-treated dogs were different from those in rats. Peroxisome proliferation is a characteristic morphological finding in rats treated with CPIB. However, in the present study, per- oxisome proliferation was not observed in dogs treated with CPIB, but mitochondrial proliferation was observed. Genomics and proteomics analyses revealed induction of neither peroxisomal $\beta$-oxidation-related genes nor $\beta$ oxidation-related proteins, such as AOX and acetyl-CoA acyltransferase. It is well known that the effects of peroxisome proliferators have species differences between rodents and non-rodents, and that rats and mice are extremely sensitive to peroxisome proliferators compared to other species (Youssef and Badr, 1998; Bentley et al., 1993; Watanabe et al., 1989). Non-rodent species, including humans, monkeys and guinea pigs, are less sensitive (Youssef and Badr, 1998; Bentley et al., 1993; Lake et al., 1989), and the peroxisome proliferation and induction of fatty acid $\beta$-oxidation are not observed in these species. There have been several reports describing changes of the mitochondrial function in response to peroxisome proliferators in non-rodent animals (Hsu et al., 2001), but there are few on morphological changes. Fenofibrate and ciprofibrate, which have higher PPAR $\alpha$ activity than CPIB, have been shown by morphometry to cause mitochondrial proliferation in monkeys (Hoivik et al., 2004). Mitochondrial and peroxisomal proliferation in the dog liver was observed when fenofibrate was administered to dogs at a high dose for 52 weeks. However, no proliferation was observed in the first 13 weeks of fenofibrate treatment (Sameshima et al., 1995). These results suggested that mitochondrial proliferation in the liver of nonrodents requires a long treatment period with a strong PPAR $\alpha$ agonist. We could detect mitochondrial proliferation in dogs by a 2-week treatment with CPIB. The regimen in the present study was increasing dosing, which may enable animals to tolerate high dose treatment and high drug exposure. Therefore, we could detect morphological changes in a shorter treatment period.

The mechanism of species differences in response to peroxisome proliferators between rodent and non-rodent species are not fully understood, but there are several possibilities that could account for this difference. First, the expression level of PPAR $\alpha$ in the human liver is lower than that in rat and mouse livers. The expression level of human PPAR $\alpha$ and its functional receptor are less than $10 \%$ of that found in rats and mice (Gervois et al., 1999; Palmer et al., 1998). Guinea pigs also show low hepatic PPAR $\alpha$ mRNA expression (Bell et al., 1998) and therefore the species differences in the response to peroxisome proliferators may be due to the different hepatic levels of PPAR $\alpha$. Second, the induction of peroxisome proliferator receptor elements (PPREs) encoding AOX gene, a latelimiting enzyme of peroxisome $\beta$-oxidation, indicates a species difference. For example, PPREs of monkeys and 
Hepatic gene and protein expression profiles in dogs
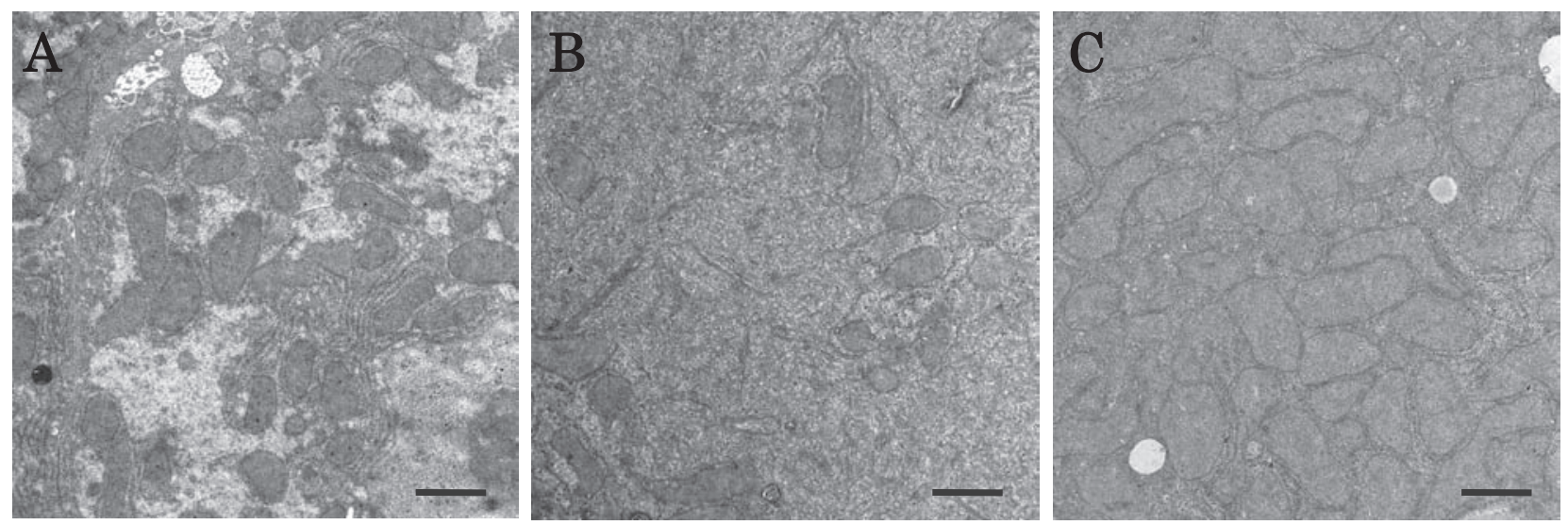

Fig. 3. Electron microscopic photographs of the livers treated with chemicals for 14 days. Bar $=1 \mu \mathrm{m}$. A: Control, B: PB, C: CPIB. Hepatocytes treated with PB showed SER proliferation and those treated with CPIB showed the proliferation of mitochondria.

humans are non-responsive to PPAR $\alpha$, although those in rats is highly responsive (Kane et al., 2006). HepG2 cells, a human hepatoma cell line engineered to express PPAR $\alpha$ similarly in the mouse liver, induced high levels of mRNA of mitochondrial enzymes such as HMG-CoA synthase, fatty acyl-CoA synthetase and carnitine palmytoyl-CoA transferase, but AOX was not induced (Hsu et al., 2001). In the present study, the AOX gene was not clearly affected by CPIB treatment in dogs, which suggests the possibility that the dog PPRE encoding AOX gene promoter is also non responsive to PPAR $\alpha$. Therefore, it is considered that dogs do not induce peroxisomal enzymes and peroxisome proliferation.

Although CPIB induces CYP4A enzyme in rats (Amacher et al., 1997; Hannon-Fletcher and Barnett, 2008), CYP4A induction by CPIB was not observed in dogs in the present study. Previous studies have also reported that CYP4A is not highly inducible by CPIB in dogs (Graham et al., 2002, 2006). Because CYP4A genes contain a functional PPRE in their promoter sequence and are activated through PPAR $\alpha$ activators (Desvergne and Wahli, 1999), there may also be similar species differences in response to peroxisome in the CYP4A induction. Further studies are needed in order to clarify the reasons of such species differences in the peroxisome response and CYP4A induction.

CYP2B, CYP3A and UDP-GT induction was observed in PB-treated dog liver by genomic analysis using Gene$\mathrm{Chip}^{\circledR}$ and Western blot. However, in the proteomic analysis using 2D-DIGE, the induction of CYP2B and CYP3A proteins could not be confirmed, while phase II enzymes such as glutathione $S$-transferase A3-3 could be detected. It has been reported that the detection of microsom-

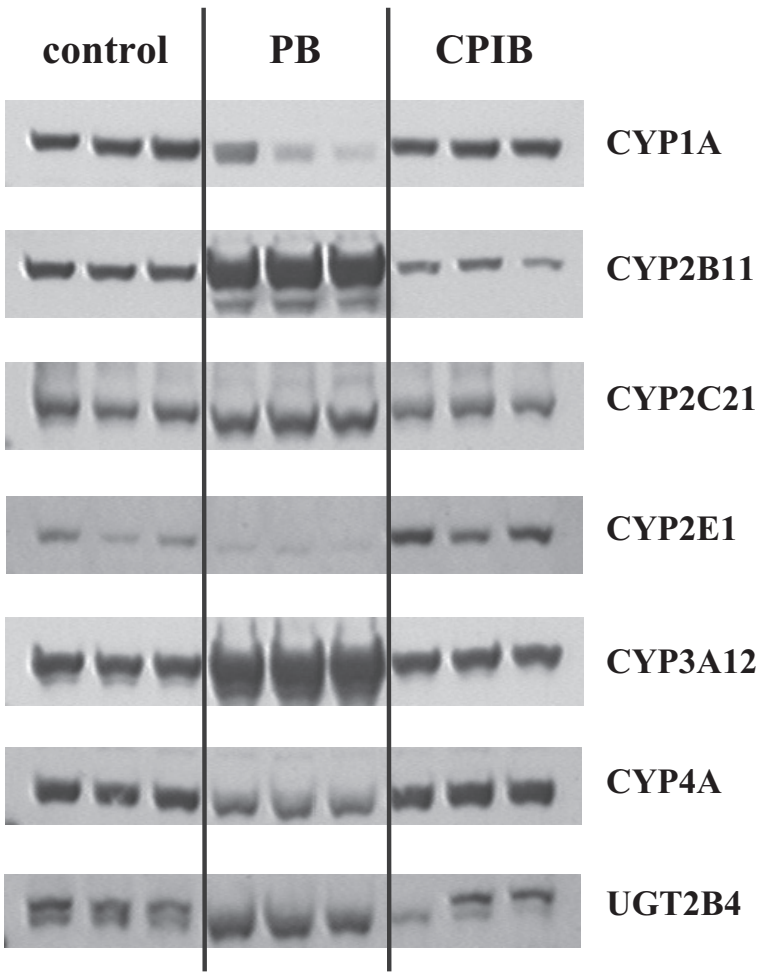

Fig. 4. Western blotting for drug-metabolizing enzymes. Samples of liver microsomes prepared from dogs treated with PB or CPIB were analyzed $(\mathrm{N}=3)$.

al membrane proteins such as cytochrome P450 (P450) by $2 \mathrm{D}$ electrophoresis is extremely difficult and there are very few reports in which $\mathrm{P} 450$ s could be detected by this procedure (Galeva and Altermann, 2002). The detection 
T. Makino et al.

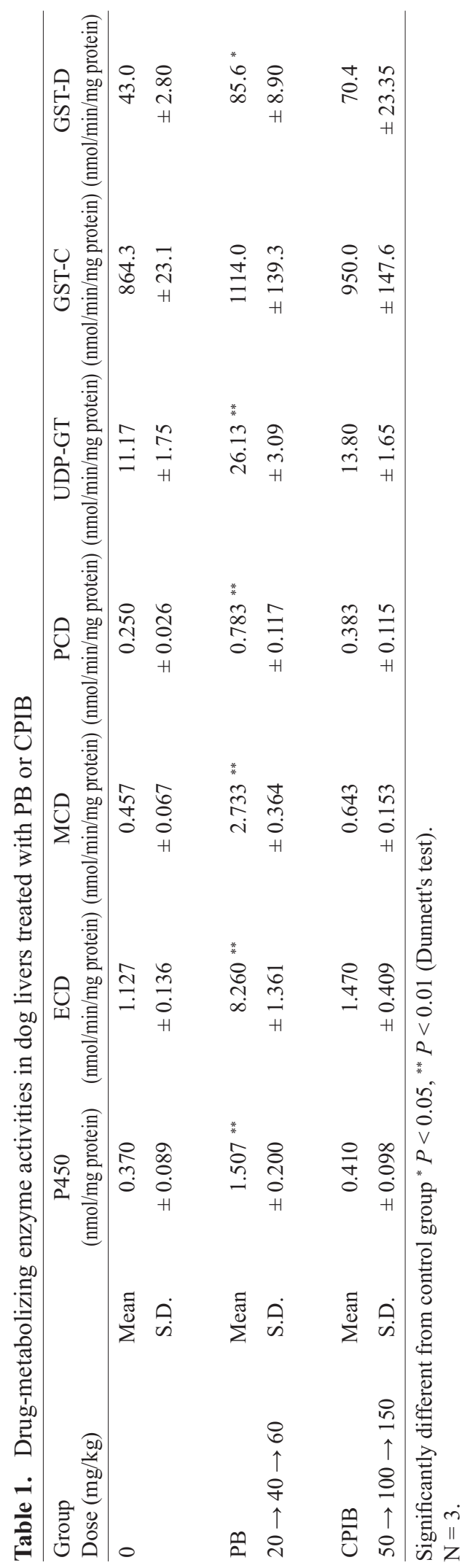


Hepatic gene and protein expression profiles in dogs

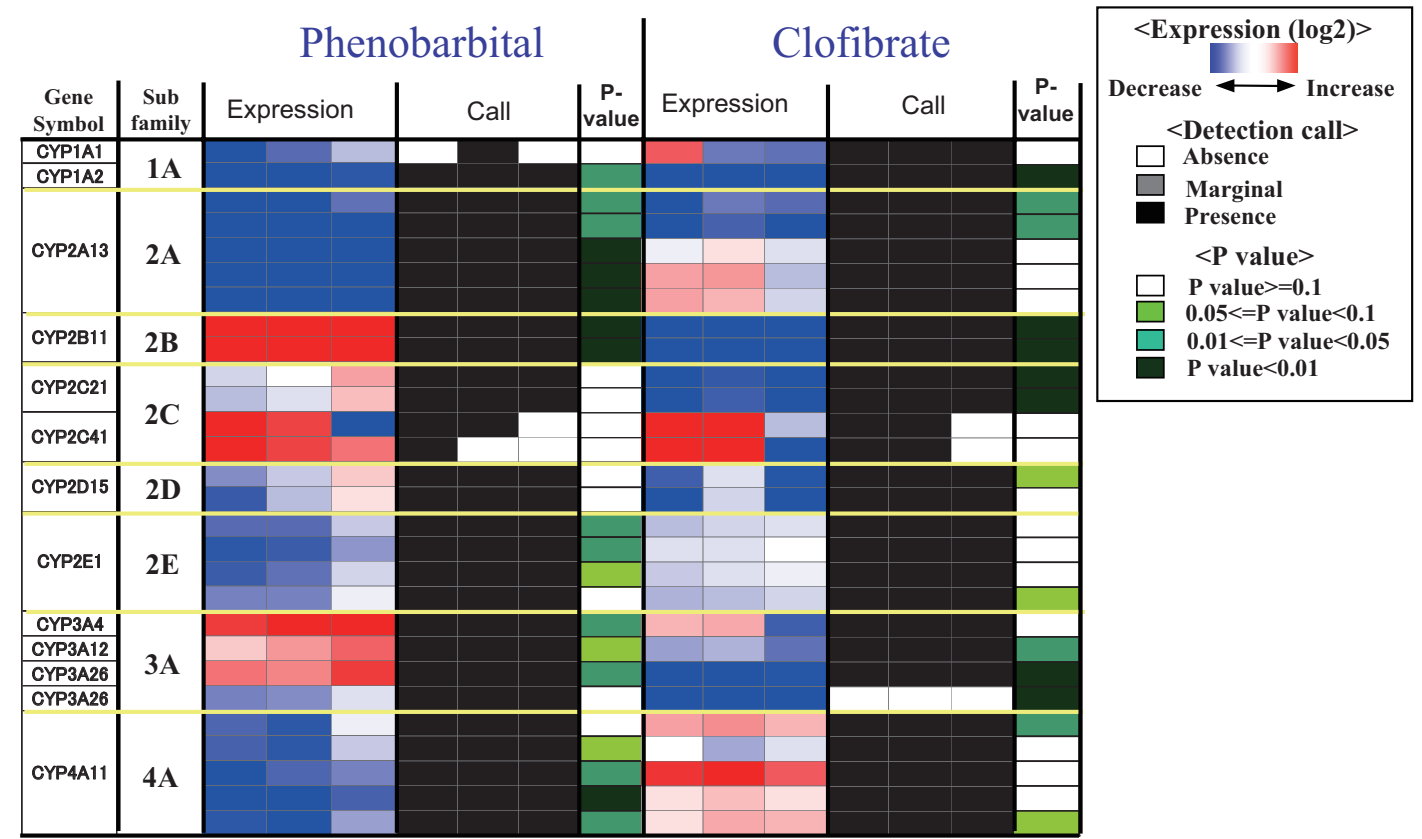

Fig. 5. CYP genes expression profiles after phenobarbital or clofibrate treatment in dogs. GeneChip data were expressed as a heat map for both Signal Log Ratio treated vs control group, Absolute Call and $p$ values. Transcript levels are colored in blue for decreasing, white for no change, and red for increasing. Absolute Calls are colored in black for Presence and white for Absence.

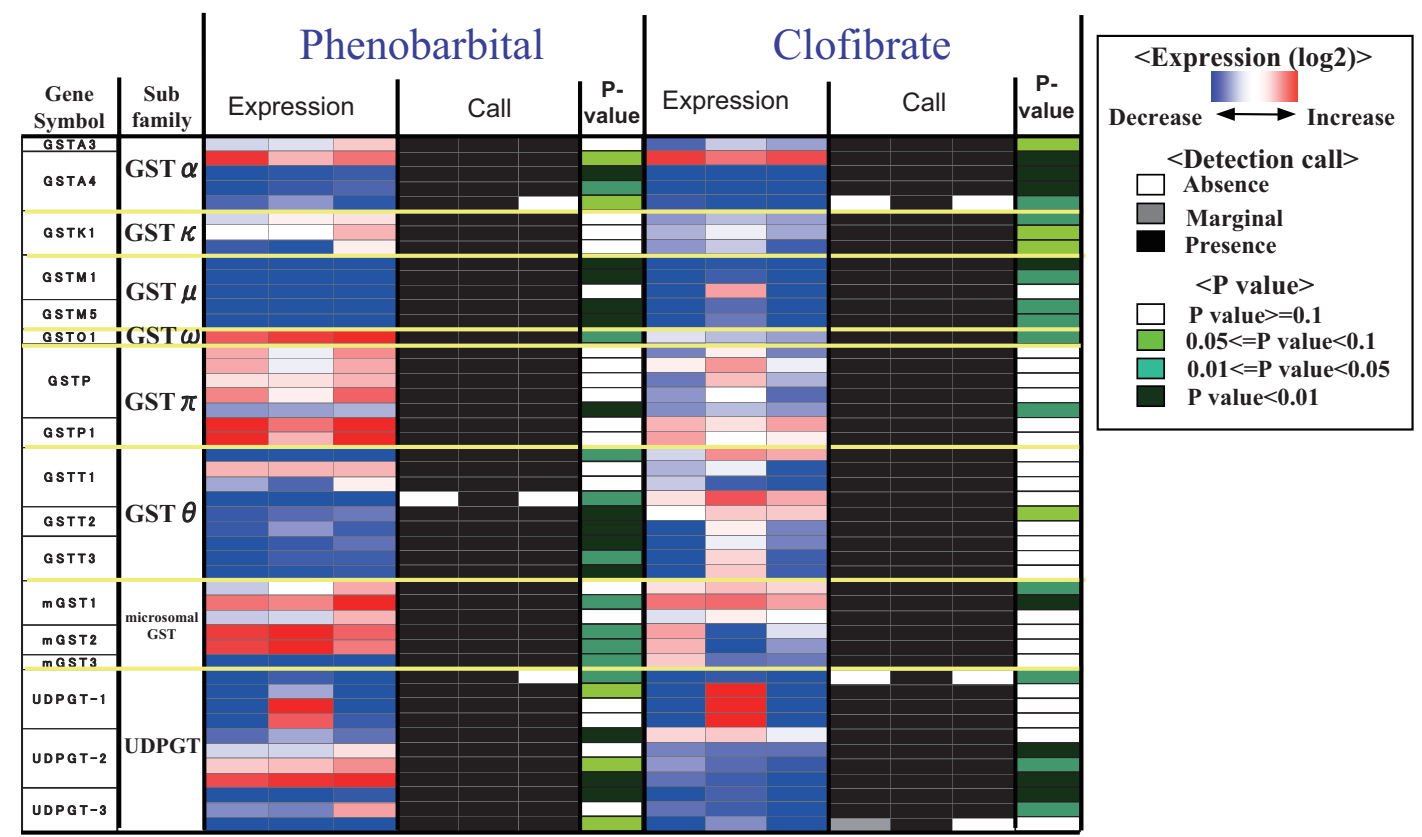

Fig. 6. GST and UDP-GT genes expression profiles after the phenobarbital or clofibrate treatment in dogs. GeneChip data were expressed as a heat map for both Signal Log Ratio treated vs control group, Absolute Call and $p$ values. Transcript levels are colored in blue for decreasing, white for no change, and red for increasing. Absolute Calls are colored in black for Presence and white for Absence. 

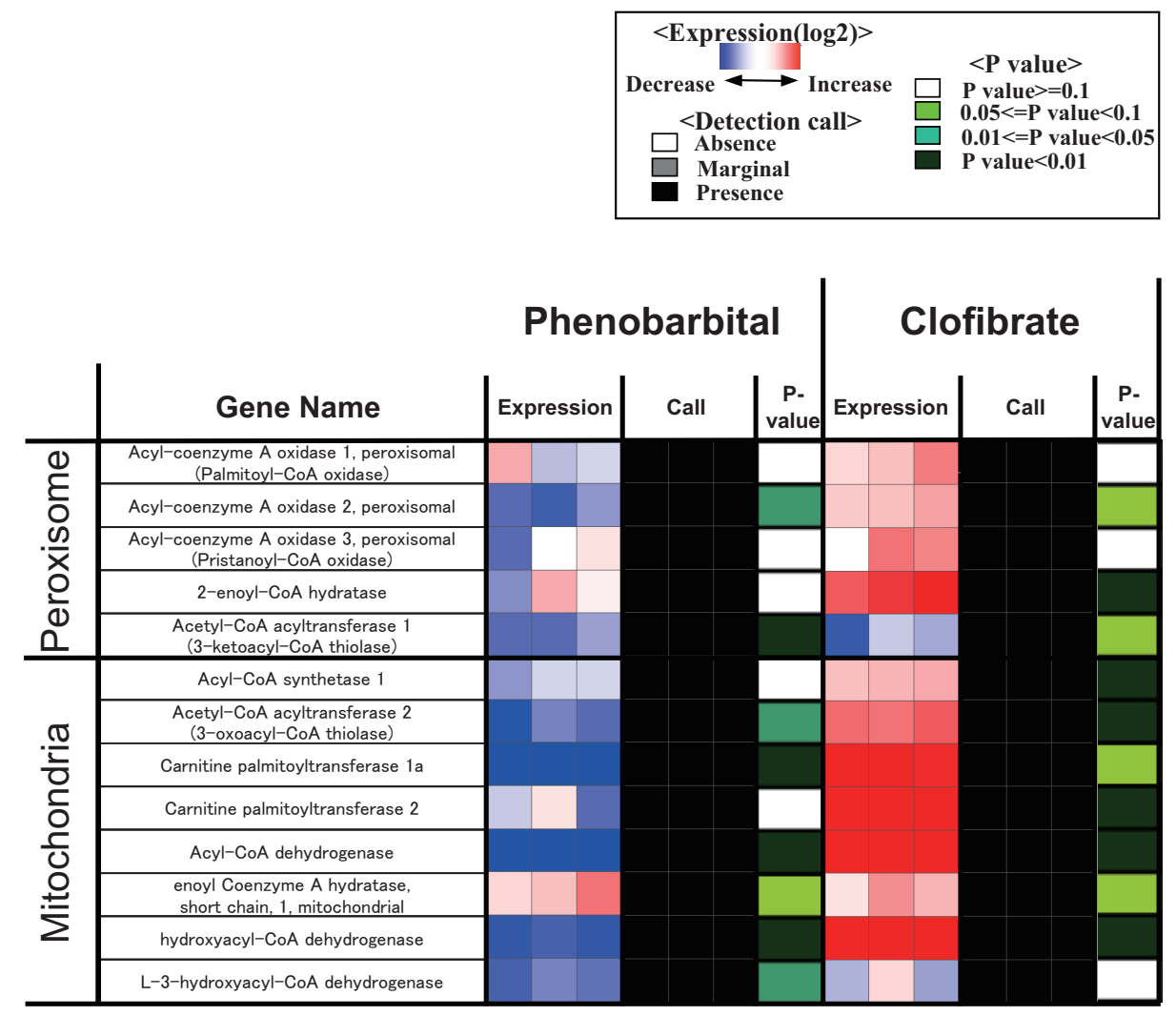

Fig. 7. Peroxisomal- or mitochondrial-genes expression profiles after the phenobarbital or clofibrate treatment in dogs. GeneChip data were expressed as a heat map for both Signal Ratio treated vs control group, Absolute Call and $p$ values. Transcript levels are colored in blue for decreasing, white for no change, and red for increasing. Absolute Calls are colored in black for Presence and white for Absence.

of $\mathrm{P} 450 \mathrm{~s}$ is difficult by $2 \mathrm{D}$ electrophoresis because the enzymes have similar molecular weights and $\mathrm{pI}$ values and the aggregation of hydrophobic molecules takes place under isoelectrofocusing conditions (Petushkova et al., 2006). The $\mathrm{pI}$ values of CYP proteins are within the range of 8.3 to 9.2 and a pI range between 7.0 and 10.0 is a poor resolution range for $2 \mathrm{D}$ electrophoresis (Petushkova et al., 2006). Several approaches have been utilized to detect $\mathrm{P} 450$ proteins by $2 \mathrm{D}$ electrophoresis, but the $2 \mathrm{D}$ DIGE procedure needs improvement in order to detect these enzymes (Galeva and Altermann, 2002; Petushkova et al., 2006).

Although the induction of CYP proteins could not be detected by 2D-DIGE, the induction of several proteins related to the ER was observed. Glucose-regulated protein 78 (GRP 78) is a well-characterized molecular chaperone that is ubiquitously expressed in mammalian cells. GRP 78 is also well-known for binding to hydrophobic patches on nascent polypeptides within the ER and for its role in signaling the unfolded protein response (Quinones et al., 2008). Carboxylesterase belongs to the $\alpha / \beta$-hydrolase family and plays an important role in the hydrolysis of many esterified drugs. Some of the isozymes are associated with cell membranes such as ER (Takahashi et al., 2009; Satoh and Hosokawa, 2006).

Microarray analysis can measure thousands of genes simultaneously and has high throughput capability (Gerhold et al., 1999), but if precise expression values are evaluated, quantitative PCR has to be performed. Evaluation using microarray analysis is based on the assumption that the protein level is regulated by transcription. Although this assumption is applicable in many cases (Celis et al., 2000), there is evidence that the transcript levels frequently do not reflect the protein levels (Gygi et al., 1999; Anderson and Seilhamer, 1997). On the other hand, proteomic analysis lacks high throughput capability and sensitivity. But, a combination of these techniques including biochemical and morphological evaluations will 
Hepatic gene and protein expression profiles in dogs

Table 2. List of proteins that were differentially expressed in the dog liver after PB treatment for 14 days

\begin{tabular}{|c|c|c|}
\hline Spot No. & Pratein Name & Fold inducti \\
\hline \multicolumn{3}{|c|}{ TCA cycle \& respiratory metabolism } \\
\hline 1480 & Isocitrate dehydrogenase [NADP] cytoplasmic isoform 1 & -1.56 \\
\hline \multicolumn{3}{|l|}{ Urea cycle } \\
\hline 1281 & Argininosuccinate lyase isoform 1 & -1.33 \\
\hline 1300 & Argininosuccinate lyase isoform 1 & 1.77 \\
\hline 1322 & Argininosuccinate lyase isoform 1 & -1.53 \\
\hline 1475 & Argininosuccinate synthase isoform 5 & -1.63 \\
\hline
\end{tabular}

Amino acid \& protein metabolism

$827 \quad$ Urocanase domain containing $1 \quad-1.40$

1258 Phenylalanine-4-hydroxylase $\quad-1.64$

1446 Adenosylhomocysteinase isoform 2 $\quad-1.45$

1520 4-hydroxyphenylpyruvate dioxygenase $\quad-1.46$

$1571 \quad$ Aspartate aminotransferase 1 isoform 2 $r .12$

1582 Aspartate aminotransferase 1 isoform $2 \quad-1.46$

Oxidative stress

$2231 \quad$ Peroxiredoxin 6

$-1.51$

2343 Glutathione S-transferase A3-3 (GST class-alpha)

Chaperonin

$\begin{array}{llr}755 & 78 \mathrm{kDa} \text { glucose-regulated protein precursor (GRP 78) isoform } 4 & 1.65\end{array}$

$76178 \mathrm{kDa}$ glucose-regulated protein precursor (GRP 78) isoform $3 \quad 2.11$

ER function

$\begin{array}{lll}1070 \quad \text { Brain carboxylesterase } \mathrm{hBr} 2 \text { [Homo sapiens] } & 2.17\end{array}$

1071 Brain carboxylesterase hBr2 [Homo sapiens] 1.51

Peroxisomal function

$1670 \quad$ Serine-pyruvate aminotransferase isoform $2 \quad-1.45$

1673 Serine-pyruvate aminotransferase isoform $2 \quad-1.60$

1689 Serine-pyruvate aminotransferase isoform $2 \quad-1.72$

Other fanction

1076 Protein disulfide isomerase-associated 3 precursor $\quad 1.71$

$\begin{array}{lr}1112 \text { UDP-glucose dehydrogenase isoform } 1 & 1.74\end{array}$

1113 UDP-glucose dehydrogenase isoform 1 $r .85$

\begin{tabular}{lr}
1144 & Formiminotransferase cyclodeaminase \\
\hline
\end{tabular}

1235 Selenium binding protein $1 \quad-1.33$

1265 Selenium binding protein $1 \quad-1.31$

$\begin{array}{llr}1456 & \text { SEC14p-like protein TAP3 } & -1.47\end{array}$

1473 SEC14-like $3 \quad-1.72$

$\begin{array}{lr}1837 \text { Crystallin, zeta isoform } 2 & 1.34\end{array}$

2217 Carbonic anhydrase III $\quad-2.10$

2916 Betaine--homocysteine S-methyltransferase $r$

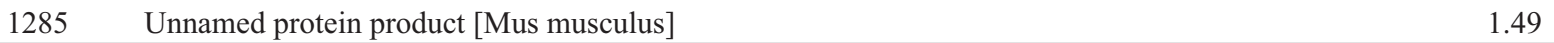

The proteins with a fold change above 1.3 or below 0.77 and a $p$ value $<0.05$ (Student's $t$-test) were listed. 
Table 3. List of proteins that were differentially expressed in the dog liver after CPIB treatment for 14 days

\begin{tabular}{|c|c|c|}
\hline \multirow{2}{*}{\multicolumn{3}{|c|}{$\begin{array}{l}\text { Spot No. Pratein Name } \\
\text { Fatty acid metabolism }\end{array}$}} \\
\hline & & \\
\hline 969 & Acyl-CoA dehydrogenase, very-long-chain specific, mitochondrial precursor (VLCAD) isoform 1 & \\
\hline 2243 & Enoyl-CoA hydratase, mitochondrial precursor & \\
\hline
\end{tabular}

Gluco- neogenesis

$\begin{array}{lll}327 & \text { Pyruvate carboxylase, mitochondrial precursor isoform 1 } & 1.54 \\ 311 & \text { Pyruvate carboxylase, mitochondrial precursor isoform 2 } & 1.72 \\ 320 & \text { Pyruvate carboxylase, mitochondrial precursor isoform 2 } & 1.71 \\ 328 & \text { Pyruvate carboxylase, mitochondrial precursor isoform 2 } & 1.54 \\ 888 & \text { Mitochondrial phosphoenolpyruvate carboxykinase 2 isoform 1 precursor isoform 3 } & 1.33\end{array}$

TCA cycle \& respiratory metabolism

$1252 \quad$ ATP synthase beta chain, mitochondrial precursor isoform $1 \quad 1.60$

1290 Dihydrolipoamide S-succinyltransferase isoform $1 \quad 1.33$

$1342 \quad$ Ubiquinol-cytochrome c reductase core protein I isoform $2 \quad 1.41$

Urea cycle

222 Carbamoyl-phosphate synthetase 1, mitochondrial isoform 20 $\quad 1.39$

241 Carbamoyl-phosphate synthetase 1, mitochondrial isoform 20 1.34

1322 Argininosuccinate lyase isoform 1 2.52

1475 Argininosuccinate synthase isoform 5 $\quad-1.34$

Amino acid \& protein metabolism

$827 \quad$ Urocanase domain containing $1 \quad-1.44$

1278 Serine hydroxymethyltransferase 1 (soluble) isoform $1 \quad-1.49$

1446 Adenosylhomocysteinase isoform $2 \quad-1.35$

Purine met.

$478 \quad 10$-formyltetrahydrofolate dehydrogenase $\quad-1.38$

$483 \quad 10$-formyltetrahydrofolate dehydrogenase $\quad-1.65$

Oxidative stress

$2231 \quad$ Peroxiredoxin $6 \quad-1.31$

2340 Glutathione S-transferase A3-3 (GST class-alpha) $\quad-1.37$

Chaperonin

$106960 \mathrm{kDa}$ heat shock protein, mitochondrial precursor (Hsp60) isoform $4 \quad 1.41$

Peroxisomal function

$1670 \quad$ Serine-pyruvate aminotransferase isoform $2 \quad-1.56$

1673 Serine-pyruvate aminotransferase isoform $2 \quad-1.32$

1689 Serine-pyruvate aminotransferase isoform $2 \quad-1.66$

Other fanction

$\begin{array}{llr}880 & \text { Annexin A6 isoform } 3 & -1.32\end{array}$

$\begin{array}{rrr}1007 & \text { GDP dissociation inhibitor } 1 & 1.37\end{array}$

1025 W02H5.8 $\quad-1.68$

$1184 \quad$ UDP-glucose pyrophosphorylase 2 isoform a isoform $1 \quad-1.73$

$\begin{array}{ll}1235 \text { Selenium binding protein } 1 & -1.31\end{array}$

1250 Chain F, The Structure Of Bovine F1-Atpase Covalently Inhibited With 4-Chloro-7-Nitrobenzofurazan 1.42

$\begin{array}{lr}1332 & \text { Keratin } 1 \text { [Homo sapiens] } \\ 1444 & 2.34\end{array}$

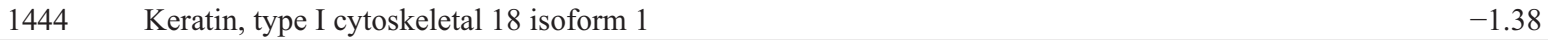

The proteins with a fold change above 1.3 or below 0.77 and a $p$ value $<0.05$ (Student's $t$-test) were listed. 
Hepatic gene and protein expression profiles in dogs

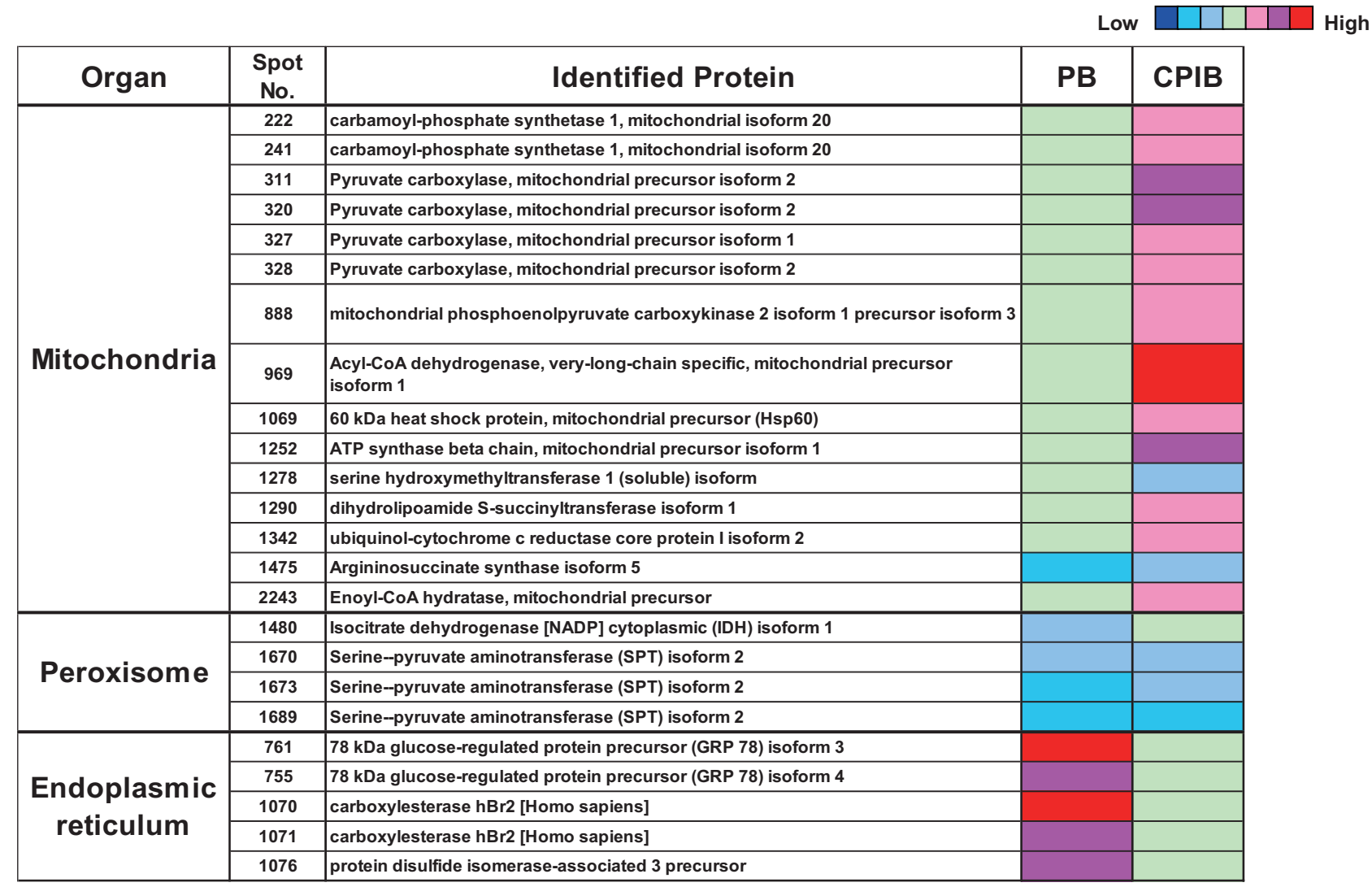

Fig. 8. Among the significant down- or up-regulated proteins in the liver of dogs treated with PB or CPIB, those related to mitochondria, peroxisome and endoplasmic reticulum are listed. Expression levels of the proteins are indicated in the blue for low expression, and red for high expression compared to that of control.

provide us with useful information about compound profiles and will be of benefit in the safety assessment.

The observations obtained in the present study suggest that there is a relatively good correlation among the morphology and the genomic and proteomic data, but some differences exist between the genomic and proteomic data in the current technical environment. Comprehensive evaluation using these techniques in addition to morphological evaluation may provide a useful tool for safety assessment of the liver.

\section{ACKNOWLEDGMENTS}

The authors thank Yukari Shibaya, Kyoko Watanabe and Shusuke Yamauchi for their excellent technical assistance.

\section{REFERENCES}

Amacher, D.E. (2006): A Toxicologist's Guide to the Preclinical Assessment of Hepatic Microsomal Enzyme Induction. Toxicol. Mech. Methods, 16, 385-394.

Amacher, D.E., Beck, R., Schomaker, S.J. and Kenny, C.V. (1997): Hepatic microsomal enzyme induction, beta-oxidation, and cell proliferation following administration of clofibrate, gemfibrozil, or bezafibrate in the CD rat. Toxicol. Appl. Pharmacol., 142, 143-150.

Anderson, L. and Seilhamer, J. (1997): A comparison of selected mRNA and protein abundances in human liver. Electrophoresis, 18, 533-537.

Bell, A.R., Savory, R., Horley, N.J., Choudhury, A.I., Dickins, M., Gray, T.J., Salter, A.M. and Bell, D.R. (1998): Molecular basis of non-responsiveness to peroxisome proliferators: the guineapig PPARalpha is functional and mediates peroxisome proliferator-induced hypolipidaemia. Biochem. J., 332, 689-693.

Bentley, P., Calder, I., Elcombe, C., Grasso, P., Stringer, D. and Wiegand, H.J. (1993): Hepatic peroxisome proliferation in rodents and its significance for humans. Food Chem. Toxicol., 31, 857-907. 
Bock, K.W., Fröhling, W., Remmer, H. and Rexer, B. (1973): Effects of phenobarbital and 3-methylcholanthrene on substrate specificity of rat liver microsomal UDP-glucuronyltransferase. Biochim. Biophys. Acta., 327, 46-56.

Bradford, M.M. (1976): A rapid and sensitive method for the quantitation of microgram quantities of protein utilizing the principle of protein-dye binding. Anal. Biochem., 72, 248-254.

Burnette, W.N. (1981): "Western blotting": electrophoretic transfer of proteins from sodium dodecyl sulfate--polyacrylamide gels to unmodified nitrocellulose and radiographic detection with antibody and radioiodinated protein A. Anal. Biochem., 112, 195203.

Celis, J.E., Kruhøffer, M., Gromova, I., Frederiksen, C., Østergaard, M., Thykjaer, T., Gromov, P., Yu, J., Pálsdóttir, H., Magnusson, N. and Ørntoft, T.F. (2000): Gene expression profiling: monitoring transcription and translation products using DNA microarrays and proteomics. FEBS Lett., 480, 2-16.

David, R.M., Moore, M.R., Cifone, M.A., Finney, D.C. and Guest, D. (1999): Chronic peroxisome proliferation and hepatomegaly associated with the hepatocellular tumorigenesis of $\mathrm{di}(2-$ ethylhexyl)phthalate and the effects of recovery. Toxicol. Sci., 50, 195-205.

Desvergne, B. and Wahli, W. (1999): Peroxisome proliferator-activated receptors: nuclear control of metabolism. Endocr. Rev., 20, 649-688.

Fruchart, J.C., Brewer, H.B.Jr. and Leitersdorf, E. (1998): Consensus for the use of fibrates in the treatment of dyslipoproteinemia and coronary heart disease. Fibrate Consensus Group. Am. J. Cardiol., 81, 912-917.

Galeva, N. and Altermann, M. (2002): Comparison of one-dimensional and two-dimensional gel electrophoresis as a separation tool for proteomic analysis of rat liver microsomes: cytochromes P450 and other membrane proteins. Proteomics, 2, 713-722.

Gerhold, D., Rushmore, T. and Caskey, C.T. (1999): DNA chips: promising toys have become powerful tools. Trends Biochem. Sci., 24, 168-173.

Gervois, P., Torra, I.P., Chinetti, G., Grötzinger, T., Dubois, G., Fruchart, J.C., Fruchart-Najib, J., Leitersdorf, E. and Staels, B. (1999): A truncated human peroxisome proliferator-activated receptor alpha splice variant with dominant negative activity. Mol. Endocrinol., 13, 1535-1549.

Gonzalez, F.J. (2002): The peroxisome proliferator-activated receptor alpha (PPARalpha): role in hepatocarcinogenesis. Mol. Cell. Endocrinol., 193, 71-79.

Graham, M.J. and Lake, B.G. (2008): Induction of drug metabolism: species differences and toxicological relevance. Toxicology, 254, 184-191.

Graham, R.A., Downey, A., Mudra, D., Krueger, L., Carroll, K., Chengelis, C., Madan, A. and Parkinson, A. (2002): In vivo and in vitro induction of cytochrome P450 enzymes in beagle dogs. Drug Metab. Dispos., 30, 1206-1213.

Graham, R.A., Goodwin, B., Merrihew, R.V., Krol, W.L. and Lecluyse, E.L. (2006): Cloning, tissue expression, and regulation of beagle dog CYP4A genes. Toxicol. Sci., 92, 356-367.

Gygi, S.P., Rochon, Y., Franza, B.R. and Aebersold, R. (1999): Correlation between protein and mRNA abundance in yeast. Mol. Cell. Biol., 19, 1720-1730.

Habig, W.H., Pabst, M.J. and Jakoby, W.B. (1974): Glutathione Stransferases. The first enzymatic step in mercapturic acid formation. J. Biol. Chem., 249, 7130-7139.

Hannon-Fletcher, M.P. and Barnett, Y.A. (2008): Lymphocyte cytochrome P450 expression: inducibility studies in male Wistar rats.
Br. J. Biomed. Sci., 65, 1-6.

Hoivik, D.J., Qualls, C.W.Jr., Mirabile, R.C., Cariello, N.F., Kimbrough, C.L., Colton, H.M., Anderson, S.P., Santostefano, M.J., Morgan, R.J., Dahl, R.R., Brown, A.R., Zhao, Z., Mudd, P.N.Jr., Oliver, W.B.Jr., Brown, H.R. and Miller, R.T. (2004): Fibrates induce hepatic peroxisome and mitochondrial proliferation without overt evidence of cellular proliferation and oxidative stress in cynomolgus monkeys. Carcinogenesis, 25, 17571769.

Hsu, M.H., Savas, U., Griffin, K.J. and Johnson, E.F. (2001): Identification of peroxisome proliferator-responsive human genes by elevated expression of the peroxisome proliferator-activated receptor alpha in HepG2 cells. J. Biol. Chem., 276, 2795027958.

Kane, C.D., Francone, O.L. and Stevens, K.A. (2006): Differential regulation of the cynomolgus, human, and rat acyl-CoA oxidase promoters by PPARalpha. Gene, 380, 84-94.

Kelley, M., Groth-Watson, A., Knoble, D. and Kornbrust, D. (1994): Induction of peroxisomal enzymes by a tetrazole-substituted 2quinolinylmethoxy leukotriene D4 antagonist. Fundam. Appl. Toxicol., 23, 298-303.

Lai, D.Y. (2004): Rodent carcinogenicity of peroxisome proliferators and issues on human relevance. J. Environ. Sci. Health. C. Environ. Carcinog. Ecotoxicol. Rev., 22, 37-55.

Lake, B.G., Evans, J.G., Gray, T.J., Körösi, S.A. and North, C.J. (1989): Comparative studies on nafenopin-induced hepatic peroxisome proliferation in the rat, Syrian hamster, guinea pig, and marmoset. Toxicol. Appl. Pharmacol., 99, 148-160.

Léonard, J.F., Courcol, M., Mariet, C., Charbonnier, A., Boitier, E., Duchesne, M., Parker, F., Genet, B., Supatto, F., Roberts, R. and Gautier, J.C. (2006): Proteomic characterization of the effects of clofibrate on protein expression in rat liver. Proteomics, 6, 19151933.

Lowry, O.H., Rosebrough, N.J., Farr, A.L. and Randall, R.J. (1951): Protein measurement with the Folin phenol reagent. J. Biol. Chem., 193, 265-275.

Makino, T., Sehata, S., Igarashi, I., Watanabe, T., Ohashi, Y., Manabe, S. and Yamoto, T. (1998): Induction of glutathione $S$ transferases and hepatocellular proliferating activities in the rat liver treated with tert-butylated hydroxyanisole, 1,2-bis(2pyridyl)ethylene, and phenobarbital. J. Toxcol. Pathol., 11, 183189.

Matsubara, T., Otsubo, S., Yoshihara, E. and Touchi, A. (1983): Biotransformation of coumarin derivatives. (2). Oxidative metabolism of 7-alkoxycoumarin by microsomal enzymes and a simple assay procedure for 7-alkoxycoumarin O-dealkylase. Jpn. J. Pharmacol., 33, 41-56.

Morimura, K., Cheung, C., Ward, J.M., Reddy, J.K. and Gonzalez, F.J. (2006): Differential susceptibility of mice humanized for peroxisome proliferator-activated receptor $\alpha$ to $\mathrm{Wy}-14,643-$ induced liver tumorigenesis. Carcinogenesis, 27, 1074-1080.

Omura, T. and Sato, R. (1964): The Carbon Monoxide-Binding Pigment of Liver Microsomes. I. Evidence for Its Hemoprotein Nature. J. Biol. Chem., 239, 2370-2378.

Palmer, C.N., Hsu, M.H., Griffin, K.J., Raucy, J.L. and Johnson, E.F. (1998): Peroxisome proliferator activated receptor-alpha expression in human liver. Mol. Pharmacol., 53, 14-22.

Petushkova, N.A., Kanaeva, I.P., Lisitsa, A.V., Sheremetyeva, G.F., Zgoda, V.G., Samenkova, N.F., Karuzina, II and Archakov, A.I. (2006): Characterization of human liver cytochromes P450 by combining the biochemical and proteomic approaches. Toxicol. In Vitro, 20, 966-974. 
Hepatic gene and protein expression profiles in dogs

Quinones, Q.J., de Ridder, G.G. and Pizzo, S.V. (2008): GRP78: a chaperone with diverse roles beyond the endoplasmic reticulum. Histol. Histopathol., 23, 1409-1416.

Sameshima, H., Haraguchi, T., Chihaya, Y., Nagata, R., Ohbayashi, S., Mogi, M. and Tsuchiya, T. (1995): Repeated oral dose toxicity study of fenofibrate in beagle dogs for 52 weeks. Jpn. Pharmacol. Ther., 23, S949-972.

Sanders, S. and Thorgeirsson, S.S. (1999): Phenobarbital promotes liver growth in c-myc/TGF-alpha transgenic mice by inducing hypertrophy and inhibiting apoptosis. Carcinogenesis, 20, 41-49.

Satoh, T. and Hosokawa, M. (2006): Structure, function and regulation of carboxylesterases. Chem. Biol. Interact., 162, 195-211.

Takahashi, S., Katoh, M., Saitoh, T., Nakajima, M. and Yokoi, T. (2009): Different inhibitory effects in rat and human carboxy- lesterases. Drug Metab. Dispos., 37, 956-961.

Watanabe, T., Horie, S., Yamada, J., Isaji, M., Nishigaki, T., Naito, J. and Suga, T. (1989): Species differences in the effects of bezafibrate, a hypolipidemic agent, on hepatic peroxisome-associated enzymes. Biochem. Pharmacol., 38, 367-371.

Yang, M.C., Ruan, Q.G., Yang, J.J., Eckenrode, S., Wu, S., McIndoe, R.A. and She, J.X. (2001): A statistical method for flagging weak spots improves normalization and ratio estimates in microarrays. Physiol. Genomics, 7, 45-53.

Youssef, J. and Badr, M. (1998): Extraperoxisomal targets of peroxisome proliferators: mitochondrial, microsomal, and cytosolic effects. Implications for health and disease. Crit. Rev. Toxicol., 28, 1-33. 